\title{
Balance of Production and Consumption of ATP in Ammonium-starved Saccharomyces cerevisiae
}

\author{
By ROSARIO LAGUNAS* AND ELVIRA RUIZ \\ Instituto de Investigaciones Biomédicas del CSIC, Facultad de Medicina de la UAM, \\ Arzobispo Morcillo 4, 28029 Madrid, Spain
}

(Received 19 November 1987; revised 7 March 1988)

\begin{abstract}
To establish a balance between the ATP produced in catabolism and the ATP consumed in net biosynthesis of cellular components the energy metabolism of Saccharomyces cerevisiae utilizing glucose in the absence of a nitrogen source (resting cells) was studied. The following results were obtained. (i) Cell number and biomass increased 2- and 2.5-fold, respectively, during the first $8 \mathrm{~h}$ of ammonium starvation. After this period, both values remained constant. (ii) The rate of sugar consumption and ATP production decreased with the duration of starvation to about $20 \%$ of the original in $24 \mathrm{~h}$. (iii) About $60 \%$ of the sugar consumed was fermented to ethanol and about $10 \%$ assimilated as cellular material. Of the assimilated sugar, as much as $80 \%$ was accumulated as carbohydrate. (iv) Only $15 \%$ of the total ATP produced in catabolism seems to be consumed in net biosynthesis and maintenance of intracellular $\mathrm{pH}$. The fate of the remaining $85 \%$ is unknown.
\end{abstract}

\section{INTRODUCTION}

Knowledge on yeast energy metabolism has increased greatly over the years (Gancedo \& Serrano, 1987) and yet several important questions remain unsolved (Lagunas, 1986). One of these is the fate of ATP produced in catabolism. Stouthamer (1973) calculated the amount of ATP required by yeast for biosynthesis of cellular material and the amount of ATP required for nutrient transport (Gancedo \& Serrano, 1987). The balance between these values and the amount of ATP produced by growing yeast on different substrates suggested that only $40 \%$ of the total ATP is spent in these functions (Lagunas, 1976; Gancedo \& Serrano, 1987). Similar results were reported in the case of bacteria (Hempfling \& Mainzer, 1975) and it was proposed that the portion of ATP which is unaccounted for might be used in maintenance of the cellular structures and preservation of ionic composition (Stouthamer \& Bettenhaussen, 1973). However, the fact that the amount of ATP required to maintain viability of starved yeast (Lagunas, 1976) and bacteria (Stouthamer \& Bettenhaussen, 1975) was negligible suggested that the non-identified ATP-consuming functions were dependent on growth and/or active metabolism (Lagunas, 1976; Gancedo \& Serrano, 1987). These hypotheses have not been proved and the fate of as much as $60 \%$ of the total ATP produced by micro-organisms is still unexplained (Lagunas, 1986; Gancedo \& Serrano, 1987).

In this work the energy metabolism of yeast consuming glucose in the absence of a nitrogen source (resting cells) was studied. Our rationale was that detection of differences in the balance between production and consumption of ATP in growing versus resting yeast could help in the identification of ATP-consuming functions related to growth. Our results indicate that although important catabolic changes occur in the shift from growing to resting conditions, the balance of the production and utilization of ATP remained constant. 


\section{METHODS}

Reagents. Enzymes and nucleotides were from Sigma. D-[U-14 C]Glucose was from Amersham. All other reagents were of analytical grade.

Strain, media and culture conditions. Saccharomyces cerevisiae strain ATCC 42407 was grown aerobically in a synthetic medium as described previously (Lagunas, 1976) with $2 \%(w / v)$ glucose as carbon source. Cells growing exponentially (about $1 \mathrm{mg}$ dry yeast $\mathrm{ml}^{-1}$ ) were harvested by centrifugation, washed with ammonium-free medium (Lagunas, 1976) and suspended in this medium in the presence of $2 \%(\mathrm{w} / \mathrm{v})$ glucose at about $0.3 \mathrm{mg}$ dry cells ml-1. The suspensions were incubated at $30^{\circ} \mathrm{C}$ anaerobically as described previously (Lagunas, 1979).

Analytical procedures. Anaerobic fermentation was measured manometrically at $30^{\circ} \mathrm{C}$ as described previously (Lagunas, 1979). Glucose metabolism was studied using D-[U-14 Clglucose. Samples (5 ml) of yeast in ammoniumfree medium, containing $2 \%(\mathrm{w} / \mathrm{v}) \mathrm{D}-\left[\mathrm{U}-{ }^{14} \mathrm{C}\right] \mathrm{glucose}\left[1 \mu \mathrm{Ci} \mathrm{mmol}^{-1}\left(37 \mathrm{kBq} \mathrm{mmol}^{-1}\right)\right]$ were placed in $50 \mathrm{ml}$ flasks. The flasks were stoppered with rubber caps fitted with a windowed plastic tube containing $2 \mathrm{ml}$ hyamine. Two hypodermic needles were passed through the caps. Nitrogen was bubbled through one needle and received after passage through the suspension in a test-tube containing $2 \mathrm{ml}$ hyamine to trap the ${ }^{1{ }^{4}} \mathrm{CO}_{2}$ produced by the cells. After $30 \mathrm{~min}$ incubation at $30^{\circ} \mathrm{C}$ with vigorous shaking, the needles were removed. At various times, $0 \cdot 1 \mathrm{ml}$ $10 \mathrm{M}-\mathrm{HCl}$ was added to the cell suspension and ${ }^{14} \mathrm{CO}_{2}$ absorption allowed to continue for a further $30 \mathrm{~min}$. Radioactivity incorporated into the cells was measured by filtering $0.5 \mathrm{ml}$ of the yeast suspension through Whatman filters; after washing with $5 \mathrm{ml}$ cold water, the filters were dried and the radioactivity counted. The radioactivity absorbed by hyamine, as well as that remaining in the medium, was determined. Glucose, ethanol, glycerol, acetaldehyde and acetate present in the media were determined by conventional enzymic methods (Lagunas, 1976) in samples filtered through Millipore filters.

Cell number was determined by plating on a solid medium containing $2 \%(\mathrm{w} / \mathrm{v})$ glucose. Cell dry wt was determined as described previously (Lagunas, 1976). Carbohydrate (Herbert et al., 1971), total protein (Jayamaran et al., 1966), lipid (Lagunas \& Gancedo, 1973) and DNA and RNA content of the cells (Schmidt \& Thannhauser, 1945) were determined as described previously. Polyphosphate content was determined using a rapid sampling method that included washing the cells with methanol/water $(50 / 50, \mathrm{v} / \mathrm{v})$ at $-40^{\circ} \mathrm{C}$ (Sáez \& Lagunas, 1976). This avoids contamination with orthophosphate present in the medium and hydrolysis of polyphosphate during sampling. Polyphosphate was extracted as described by Harold (1966) and hydrolysed by heating at $95^{\circ} \mathrm{C}$ in the presence of $5 \mathrm{M}-\mathrm{HCl}$. The resulting orthophosphate was determined as described by Bernhart \& Wreath (1955).

\section{RESULTS AND DISCUSSION}

\section{Contribution of different catabolic pathways to glucose utilization by ammonium-starved cells}

Anaerobic conditions were used because, in the absence of oxygen, glycolysis is the only known pathway to produce ATP, and therefore the amount of ATP formed in catabolism can be calculated easily. Ethanol and glycerol production accounted for 66 and $8 \%$, respectively, of the total sugar consumed whereas acetic fermentation accounted for only $1.5 \%$ (Table 1 ). Acetaldehyde was not detected. However, some excretion of this metabolite, followed by evaporation, seems likely as its boiling point is $20^{\circ} \mathrm{C}$ and the experiments were done at $30^{\circ} \mathrm{C}$. In favour of this hypothesis is the excess of $\mathrm{CO}_{2}$ recovered over two-carbon compounds that accumulated in the medium. This excess of $\mathrm{CO}_{2}$ cannot be ascribed to operation of the pentose

\section{Table 1. Assimilation and fermentation products accumulated in the medium during catabolism of glucose by ammonium-starved yeast}

Yeast cells were grown aerobically, harvested during exponential growth, suspended in ammonium-free medium containing $2 \%(\mathrm{w} / \mathrm{v}) \mathrm{D}-\left[\mathrm{U}^{-14} \mathrm{C}\right] \mathrm{glucose}\left[1 \mu \mathrm{Ci} \mathrm{mmol}^{-1}\left(37 \mathrm{kBq} \mathrm{mmol}^{-1}\right)\right]$ and incubated anaerobically. Values are means \pm SD (eight experiments).

Duration of ammonium starvation

\begin{abstract}
Glucose consumed
\end{abstract}

$$
\mathrm{CO}_{2} \quad \text { Ethanol }
$$$$
\text { Glycerol }
$$

Acetaldehyde

Acetate

[ $\mu \mathrm{mol}(\mathrm{ml} \text { culture })^{-1}$ ]

$$
51 \pm 7
$$$$
72 \pm 5
$$

$$
75 \pm 7 \quad 66 \pm 8
$$$$
125 \pm 14 \quad 97 \pm 12
$$

$4.5 \pm 0 \cdot 3$

$7.0 \pm 0.05$

$7.3 \pm 0.9$
$11.8 \pm 0.6$

$$
\begin{aligned}
& <1.0 \\
& <1.0
\end{aligned}
$$




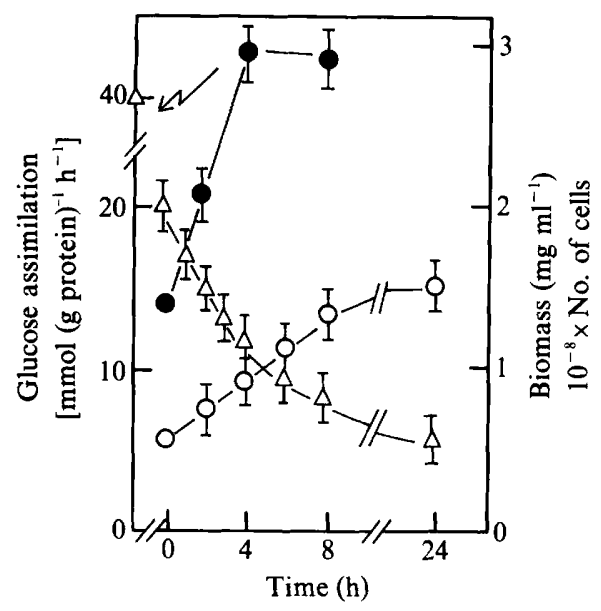

Fig. 1. Changes during ammonium starvation. Cells were grown aerobically, harvested during exponential growth, suspended in ammonium-free medium containing $2 \%(w / v)$ glucose and incubated anaerobically. $\triangle$, Glucose assimilation; $O$, biomass; $O$, cell number. Values are means $\pm S D$ of eight experiments.

\section{Table 2. Content of cellular components}

Cells were grown and treated as described in Table 1 . Values are means \pm SD (eight experiments).

\section{Duration of} ammonium starvation

(h)

$$
\begin{gathered}
\text { Yeast } \\
\text { dry wt }
\end{gathered}
$$

$$
\text { Carbohydrate }
$$

$$
\begin{gathered}
\text { Protein Lipid } \\
{\left[\mu \mathrm{g}(\mathrm{ml} \text { suspension })^{-1}\right]}
\end{gathered}
$$

DNA

RNA

Polyphosphate

$\begin{array}{rl}0 & 390 \\ 6 & 649 \\ 24 & 944\end{array}$

$$
\begin{aligned}
& 105 \pm 15 \\
& 259 \pm 40
\end{aligned}
$$

$649 \quad 259 \pm 40$

$168 \pm 14$
$197 \pm 41$
$183 \pm 22$

5
14
19

$8 \pm 3 \cdot 6$
$8 \pm 1 \cdot 1$
$9 \pm 0.8$

$52 \pm 5 \cdot 9$

$9 \pm 2 \cdot 5$

$67 \pm 7 \cdot 0$

$18 \pm 3 \cdot 8$

$64 \pm 5 \cdot 9$

$30 \pm 8 \cdot 8$

phosphate pathway since the contribution of this pathway to glucose catabolism is quite small (Lagunas \& Gancedo, 1973). The results suggest that only about $10 \%$ of the total sugar consumed was assimilated into cellular material.

A similar contribution of the different pathways to the one observed here with resting yeast has been reported with growing yeast (Lagunas, 1976), indicating that catabolism of glucose is similar under both conditions.

\section{Changes during ammonium starvation}

Fermentation of glucose by exponentially growing yeast occurred at about $40 \mathrm{mmol}$ glucose (g protein) $)^{-1} \mathrm{~h}^{-1}$ (Fig. 1). However, as soon as these cells were transferred to a medium lacking a nitrogen source the fermentation rate dropped to $50 \%$ of the initial value, possibly as a consequence of the effect of ammonium ion on phosphofructokinase (Ramaiah, 1974). As ammonium starvation proceeded, the fermentation rate decreased progressively as a consequence of the irreversible inactivation of glucose transport in resting cells (Lagunas $e t$ al., 1982).

Cell number increased about 2-fold during $4 \mathrm{~h}$ of ammonium starvation (Fig. 1). Other metabolic conditions in which cell division proceeds in the absence of a nutrient have been reported (Hartwell, 1974). The increase in cell number was accompanied by an assimilation of sugar that occurred at a constant rate for about $8 \mathrm{~h}$. During this period, biomass increased about 2.5-fold. Afterwards, this parameter remained almost constant (Fig. 1).

Cellular composition changed during ammonium starvation as shown in Table 2. 
Table 3. Calculated ATP consumption in the net biosynthesis of the cellular components

The values have been calculated, as described by Stouthamer (1973), from the data in Table 2. The following assumptions were made: polymerization of glucose to polysaccharide $\left(\mathrm{C}_{6} \mathrm{H}_{28} \mathrm{O}_{5}\right)_{n}$ requires $2 \mathrm{~mol}$ of ATP per monomer; synthesis of fatty acids $\left(\mathrm{C}_{16} \mathrm{H}_{28} \mathrm{O}_{2}\right)$ requires $16 \mathrm{~mol}$ of ATP mol-1; synthesis and polymerization of RNA $\left(\mathrm{C}_{10} \mathrm{~N}_{5} \mathrm{H}_{14} \mathrm{O}_{6}\right)_{n}$ require $10 \mathrm{~mol}$ of ATP per monomer; transport of orthophosphate and polymerization to polyphosphate $\left(\mathrm{PO}_{2} \mathrm{H}\right)_{n}$ require $2 \mathrm{~mol}$ of ATP per monomer.

\begin{tabular}{lcc} 
Cellular & \multicolumn{2}{c}{$\begin{array}{c}\text { ATP consumed } \\
\text { (mmol per } 100 \text { mmol glucose utilized) }\end{array}$} \\
\cline { 2 - 3 } $\begin{array}{c}\text { Ammonium starvation } \\
\text { for } 6 \mathrm{~h}\end{array}$ & $\begin{array}{c}\text { Ammonium starvation } \\
\text { for } 24 \mathrm{~h}\end{array}$ \\
Carbohydrate & 3.8 & 7.2 \\
Lipid & 0.8 & 0.9 \\
RNA & 1.0 & 0.6 \\
Polyphosphate & 0.6 & 1.0 \\
Total & 6.2 & 9.7
\end{tabular}

Carbohydrate content increased 5 -fold in $24 \mathrm{~h}$ whereas lipid and polyphosphate content increased about 3-fold. Significant increments of other cellular components were not detected. These results indicate that as much as $80 \%$ of the assimilated sugar was accumulated by the cells as carbohydrate, most likely as glycogen and trehalose (Lillie \& Pringle, 1980). They also indicate that whereas carbohydrate and protein content accounted for 26 and $41 \%$, respectively, of the cellular material of growing yeast, they accounted for as much as 56 and $18 \%$ in resting yeast.

\section{Balance of the production and utilization of $A T P$}

Production of ATP in catabolism of glucose can be calculated since each mol of sugar transformed into ethanol and acetate produces a net gain of 2 mol of ATP, and a net expenditure of $2 \mathrm{~mol}$ of ATP takes place in the transformation of $1 \mathrm{~mol}$ of sugar to glycerol. On the other hand, an approximate estimation of the amount of ATP required for the formation of cellular material can also be done taking into account the amount of ATP spent in biosynthesis and polymerization of macromolecules (Stouthamer, 1973). According to these calculations, the data in Table 1 indicate that resting yeast produces about $120 \mathrm{~mol}$ of ATP per $100 \mathrm{~mol}$ of catabolized hexose. They also indicate that the biosynthesis of accumulated compounds from a similar amount of hexose requires 6 to $10 \mathrm{~mol}$ of ATP (Table 3). A comparison of both values suggests that, of the overall ATP produced in catabolism by resting yeast, only $10 \%$ is used in synthesis of cellular components the remainder being spent in functions other than net biosynthesis. One of these functions could be related to the maintenance of intracellular $\mathrm{pH}$. In our experimental conditions the plasma membrane ATPase would be mainly responsible for the extrusion of $\mathrm{H}^{+}$ coming from passive influx from the medium, and from the acetic and succinic acid produced in catabolism (Gancedo \& Serrano, 1987). Passive influx of $\mathrm{H}^{+}$through the plasma membrane occurs at a rate of about $2 \mu \mathrm{mol}(\mathrm{g} \mathrm{dry} \mathrm{wt})^{-1} \min ^{-1}$ (Leao \& van Uden, 1984) and about $1 \%$ of glucose is metabolized to acetate (Table 1) and succinate (Gancedo \& Serrano, 1987). These data and those in Table 1 suggest that of the $120 \mathrm{~mol}$ of ATP produced in the catabolism of $100 \mathrm{~mol}$ of glucose, only about $5 \mathrm{~mol}$ are spent in maintenance of the cellular $\mathrm{pH}$. This assumes that all $\mathrm{CO}_{2}$ produced in fermentation is excreted as gas without expenditure of ATP. However, the possibility that $\mathrm{CO}_{2}$ is excreted as carbonic acid cannot be excluded, and, in this case, an enormous amount of ATP would be needed to maintain cellular $\mathrm{pH}$. Our observations indicate that the proportion of energy spent in functions not directly related to biosynthesis is similar in growing and in resting yeast. The possibility that a high expenditure of ATP is required to excrete $\mathrm{CO}_{2}$ in the form of carbonic acid should be seriously considered.

We are grateful to Drs C. Gancedo and J. M. Gancedo for critical reading of this manuscript. This work was supported by Comisión Asesora para la Investigación Científica y Técnica y por el Fondo de Investigaciones Sanitarias. 


\section{REFERENCES}

Bernhart, D. N. \& Wreath, A. (1955). Colorimetric determination of orthophosphate by modified phosphomolybdate method. Analytical Chemistry 27, 440-441.

Gancedo, C. \& Serrano, R. (1987). Energy metabolism in yeast. In The Yeasts, 2nd edn. Edited by A. H. Rose \& J. S. Harrison. London: Academic Press.

HAROLD, F. M. (1966). Inorganic polyphosphates in biology: structure, metabolism and function. Bacteriological Reviews 30, 772-794.

HARTWELL, L. H. (1974). Saccharomyces cerevisiae cell cycle. Bacteriological Reviews 38, 164-198.

Hempfling, W. P. \& Mainzer, S. E. (1975). Effects of varying the carbon source limiting growth on yield and maintenance characteristics of $E$. coli in continuous culture. Journal of Bacteriology 123, 1076-1087.

Herbert, D., Phipps, P. J. \& Strange, R. E. (1971). Chemical analysis of microbial cells. Methods in Microbiology 5B, 210-236.

Jayamaran, J., Cotman, C., Mahler, H. M. \& SharP, C. V. (1966). Biochemical correlation of respiratory deficiency. VII. Glucose repression. Archives of Biochemistry and Biophysics 116, 224-252.

LaGUNAS, R. (1976). Energy metabolism of Saccharomyces cerevisiae. Discrepancy between ATP balance and known metabolic functions. Biochimica et biophysica acta 440, 661-674.

LAGUNAS, R. (1979). Energetic irrelevance of aerobiosis for S. cerevisiae growing on sugars. Molecular and Cellular Biochemistry 27, 139-146.

LAGUNAS, R. (1986). Misconceptions about the energy metabolism of Saccharomyces cerevisiae. Yeast 2, 221-228.

Lagunas, R. \& Gancedo, J. M. (1973). Reduced pyridine-nucleotides balance in glucose growing Saccharomyces cerevisiae. European Journal of Biochemistry 37, 90-94. lagunas, R., Dominguez, C., Busturia, A. \& SaÉz, M. J. (1982). Mechanisms of appearance of the Pasteur effect in Saccharomyces cerevisiae: inactivation of sugar transport systems. Journal of Bacteriology 152, 19-25.

LEAO, C. \& VAN UDEN, N. (1984). Effects of ethanol and other alkanols on passive proton influx in the yeast Saccharomyces cerevisiae. Biochimica et biophysica acta 774, 43-48.

Lillie, S. H. \& PRINGle, J. R. (1980). Reserve carbohydrate metabolism in Saccharomyces cerevisiae. Response to nutrient limitation. Journal of Bacteriology 143, 1384-1394.

Ramaiah, A. (1974). Pasteur effect and phosphofructokinase. Current Topics in Cellular Regulation 8, 297345.

SAÉz, M. J. \& LaGUNas, R. (1976). Determination of intermediary metabolites in yeast. Critical examination of the effect of sampling conditions and recommendations for obtaining true levels. Molecular and Cellular Biochemistry 13, 73-78.

SCHMIDT, G. \& ThanNhauser, S. J. (1945). A method for the determination of desoxyribonucleic acid, ribonucleic acid and phosphoproteins in animal tissues. Journal of Biological Chemistry 161, 83-89.

Stouthamer, A. H. (1973). A theoretical study on the amount of ATP required for synthesis of microbial cell material. Antonie van Leeuwenhoek 39, 545-565. Stouthamer, A. H. \& Bettenhaussen, C. V. (1973). Utilization of energy for growth and maintenance in continuous and batch cultures of microorganisms. A re-evaluation of the method for the determination of ATP production by measuring molar growth yields. Biochimica et biophysica acta 301, 53-70.

Stouthamer, A. H. \& Bettenhaussen, C. W. (1975). Determination of the efficiency of oxidative phosphorylation in continuous cultures of Aerobacter aerogenes. Archives of Microbiology 102, 187-192. 